International Journal of Innovative Studies in Aquatic Biology and Fisheries

Volume 4, Issue 1, 2018, PP 20-25

ISSN 2454-7662 (Print) \& ISSN 2454-7670 (Online)

DOI: http://dx.doi.org/10.20431/2454-7670.0401004

www.arcjournals.org

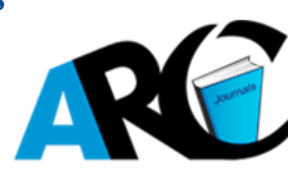

\title{
Predata on Some Morphometric Characters and Condition Factors of Crayfish, Astacus leptodactylus (Eschscholtz, 1823) from Kılıçkaya Reservoir, Sivas, Turkey
}

\author{
Seher Dirican* \\ Department of Fisheries, Vocational Training School of Suşehri Timur Karabal, Cumhuriyet University TR- \\ 58600 Sivas, Turkey.
}

* Corresponding Author: Seher Dirican, Department of Fisheries, Vocational Training School of Suşehri Timur Karabal, Cumhuriyet University TR-58600 Sivas, Turkey.

\begin{abstract}
The aim of this study is to provide initial data on some morphometric characters and condition factors of inland water crayfish, Astacus leptodactylus (Eschscholtz, 1823) from Kllıçkaya Reservoir in Turkey. The study was performed between August and October 2014. Differences of sex groups were also investigated. Sampled population was composed of $40 \%$ female and $60 \%$ male specimens. Results of the study

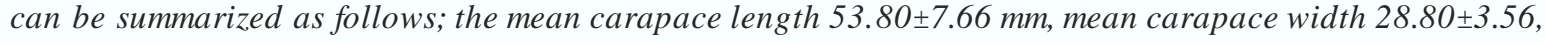

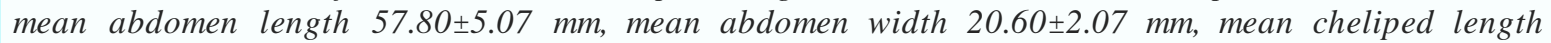
$46.40 \pm 15.40 \mathrm{~mm}$, mean cheliped width $17.80 \pm 4.60 \mathrm{~mm}$, mean total length $111.60 \pm 12.07 \mathrm{~mm}$, mean total weight $37.63 \pm 16.49 \mathrm{~mm}$ and mean condition factor $2.58 \pm 0.29 \mathrm{~mm}$ from Kllcçkaya Reservoir. The obtained predata results were compared with other studies from different aquatic habitats.
\end{abstract}

Keywords: Crayfish, Condition Factors, Morphometric Characters, Kılıçkaya Reservoir.

\section{INTRODUCTION}

Crayfish play an important role in the natural balance of inland ecosystems, influencing the distribution and abundance of other aquatic organisms through their omnivory and bioturbatory behaviour. Crayfish that is a very good of economic value have a key role organism in protecting of the ecological balance of inland water resources $[1,2]$. Crayfish shows distribution in many parts of the world is the invertebrate animals that has an economic and ecological importance. Crayfish has two species, which are Astacus leptodactylus and Austropotamobius torrentium in Turkey. A. leptodactylus in Anatolia, it has a qualify that only species in the source of many inland water as natural distribution. Supply of this species is only from crayfish fisheries and nearly all the production is exported. This species is not only important for its economic value but also for its important role playing in inland aquatic food web. Austropotamobius torrentium is the only species that not natural for inland waters of Turkey and first time recorded 2005 within the boundaries of Kurklareli Velika creek, and Madara creek in 2007. However, Austropotamobius torrentium is of little commercial interest because it relatively small size [3-5]. A. leptodactylus is widely distributed in lakes, reservoirs, ponds and rivers throughout the Turkey. Until the end of 1984, it has been the most important inland fisheries product in Turkey. However, the spread of the crayfish plaque in inland waters in 1984, declined the production values sharply in Turkey [4]. After the crayfish disease in 1985, stocks dropped rapidly and production, which totaled 7.936 tons in 1984, decreased to 324 tons in 1992 [6]. In 2013, crayfish production was 532.1 tons in inland waters of Turkey [7]. A. leptodactylus has also been uncontrollably transferred in recent years into many inland ecosystems in Turkey to establish new populations and to restore the crayfish stocks devastated by the plague disease. Therefore, the distribution of all populations of A. leptodactylus in Turkey is not known completely [8]. A. leptodactylus has no commercial importance for Kilıçkaya Reservoir. Because it is not commercially catch in Kılıçkaya Reservoir. In addition, to the best of our knowledge no information currently exists on the some morphometric characters and condition factors of $A$. leptodactylus from K1liçkaya Reservoir. The main objective of the present study is to get information on the some morphometric characters and condition factors of A. leptodactylus from Kilıçkaya Reservoir. This information can be useful in the species conservation and the development of sustainable management strategies for the fisheries of Kulıçkaya Reservoir. 
Predata on Some Morphometric Characters and Condition Factors of Crayfish, Astacus leptodactylus (Eschscholtz, 1823) from Kılıçkaya Reservoir, Sivas, Turkey

\section{Materials ANd Methods}

\subsection{Study Area}

The study area is Kilıçkaya Reservoir located at Central Anatolian region of Turkey. Kulıçkaya Reservoir is $25 \mathrm{~km}$ north of town of Suşehri $158 \mathrm{~km}$ northeast of Sivas province in center east of Turkey. Geographical coordinates of Kilçkkaya Reservoir are $40^{\circ} 14^{\prime} 0^{\prime \prime} \mathrm{N}$ and $38^{\circ} 11^{\prime} 0^{\prime \prime} \mathrm{E}$. The Kılıçkaya Dam was constructed between 1980 and 1989 on the Kelkit Stream, a tributary of Yeşilırmak River. Kılıçkaya Dam is a $132 \mathrm{~m}$ high rockfill a power plant. The water of Kulıçkaya Reservoir is mainly used for production of electrical energy, commercial fishing, irrigation, and recreation. The European catfish, Silurus glanis is intensively catch for commercial fishing in Kılıçkaya Reservoir. The substratum of the reservoir is generally muddy. The surface area and maximum depth of the Kiliçkaya Reservoir are $64.4 \mathrm{~km}^{2}$ and $100 \mathrm{~m}$ respectively [9].

\subsection{Sample Collection and Data Analysis}

Specimens of A. leptodactylus were collected from Kılıçkaya Reservoir by nets of 30 and $50 \mathrm{~mm}$ mesh sizes equipment, respectively between August and October 2014 and preserved 5\% solution of formaldehyde. The specimens was sorted into 2 groups based on sex. Some morphometric characters such as the carapace length $(\mathrm{CL})$ in $\mathrm{mm}$, carapace width $(\mathrm{CW})$ in $\mathrm{mm}$, abdomen length $(\mathrm{AL})$ in $\mathrm{mm}$, abdomen width $(\mathrm{AB})$ in $\mathrm{mm}$, cheliped length $(\mathrm{ChL})$ in $\mathrm{mm}$, cheliped width $(\mathrm{ChW})$ in $\mathrm{mm}$, total length (TL) in $\mathrm{mm}$ and total weight (TW) in $\mathrm{g}$ of the samples were measured by following $[10,11]$. All of the morphometric characters were measured using digital calipers $(0.01 \mathrm{~mm}$ of precision). The total weight of each specimen was taken using a digital balance with a precision of $0.0001 \mathrm{~g}$. The condition factor $(\mathrm{K})$ was calculated from the formula, $\mathrm{K}=100 \mathrm{~W} / \mathrm{L}^{3}$, where $\mathrm{W}(\mathrm{g})$ is observed total body weight and $\mathrm{L}(\mathrm{cm})$ is total body length [12]. SPSS for windows version 17.5 statistical software was used for all data analysis.

\section{RESULTS}

A total of five specimens of A. leptodactylus (3 male and 2 female) were collected from Kilıçkaya Reservoir. Sex composition was $60 \%$ male and $40 \%$ female in Kilçkaya Reservoir. The sex ratio coincides with the A. leptodactylus caught in Kilıckaya Reservoir where males are the dominant sex. Some morphometric characters and condition factors of A. leptodactylus from Kilıçkaya Reservoir are given for males, females, and combined sexes in Table 1. The mean carapace length of $A$. leptodactylus samples from Kilıçkaya Reservoir was $53.80 \mathrm{~mm}( \pm \mathrm{SD} 7.66$; min. $46 \mathrm{~mm}$; max. 65 $\mathrm{mm})$. The mean carapace length of males was $54.00 \mathrm{~mm}( \pm \mathrm{SD} 9.85$; $\min .46 \mathrm{~mm}$; max. $65 \mathrm{~mm})$ and mean carapace length of females was $53.50 \mathrm{~mm}( \pm \mathrm{SD} 6.36$; min. $49 \mathrm{~mm}$; max. $58 \mathrm{~mm})$ from Kilıçkaya Reservoir. The mean carapace width of A. leptodactylus samples from Kılıçkaya Reservoir was $28.80 \mathrm{~mm}$ ( $\pm \mathrm{SD} 3.56$; min. $25 \mathrm{~mm}$; max. $34 \mathrm{~mm}$ ). Mean carapace width of males was $29.33 \mathrm{~mm}$ $( \pm$ SD 4.51 ; min. $25 \mathrm{~mm}$; max. $34 \mathrm{~mm})$ and mean carapace width of females was $28.00 \mathrm{~mm}( \pm \mathrm{SD}$ 2.83; min. $26 \mathrm{~mm}$; max. $30 \mathrm{~mm}$ ) from Kulıçkaya Reservoir (Table 1).

Table1.Some Morphometric Characters and Condition Factors of Astacus leptodactylus from Kılıçkaya Reservoir.

\begin{tabular}{|c|c|c|c|c|c|c|c|c|c|c|c|c|}
\hline \multirow[b]{2}{*}{ SMC } & \multicolumn{4}{|c|}{ Males } & \multicolumn{4}{|c|}{ Females } & \multicolumn{4}{|c|}{ Males+Females } \\
\hline & Min. & Max. & Mean & \pm SD & Min. & Max. & Mean & \pm SD & Min. & Max. & Mean & $\pm \mathrm{SD}$ \\
\hline $\mathrm{CL}$ & 46 & 65 & 54.00 & 9.85 & 49 & 58 & 53.50 & 6.36 & 46 & 65 & 53.80 & 7.66 \\
\hline $\mathrm{CW}$ & 25 & 34 & 29.33 & 4.51 & 26 & 30 & 28.00 & 2.83 & 25 & 34 & 28.80 & 3.56 \\
\hline $\mathrm{AL}$ & 53 & 66 & 59.33 & 6.51 & 55 & 56 & 55.50 & 0.71 & 53 & 66 & 57.80 & 5.07 \\
\hline $\mathrm{AW}$ & 18 & 23 & 21.00 & 2.65 & 19 & 21 & 20.00 & 1.41 & 18 & 23 & 20.60 & 2.07 \\
\hline $\mathrm{ChL}$ & 32 & 66 & 46.67 & 17.47 & 33 & 59 & 46.00 & 18.38 & 32 & 66 & 46.40 & 15.40 \\
\hline $\mathrm{ChW}$ & 12 & 23 & 18.33 & 5.69 & 14 & 20 & 17.00 & 4.24 & 12 & 23 & 17.80 & 4.60 \\
\hline $\mathrm{TL}$ & 99 & 131 & 113.33 & 16.26 & 105 & 113 & 109.00 & 5.66 & 99 & 131 & 111.60 & 12.07 \\
\hline TW & 23.27 & 65.18 & \begin{tabular}{|l|l|}
42.39 \\
\end{tabular} & \begin{tabular}{|l|}
21.19 \\
\end{tabular} & 27.37 & 33.62 & 30.50 & 4.42 & 23.27 & 65.18 & \begin{tabular}{|l|}
37.63 \\
\end{tabular} & 16.49 \\
\hline $\mathrm{CF}$ & 2.40 & 2.91 & 2.74 & 0.29 & 2.33 & 2.36 & 2.35 & 0.02 & 2.33 & 2.91 & 2.58 & 0.29 \\
\hline
\end{tabular}

Explanations: SMC - some morphometric characters, CL - carapace length, CW - carapace width, AL abdomen length, AW - abdomen width, ChL - cheliped length, ChW - cheliped width, TL - total length, TW total weight, CF - condition factor, Min. - minimum, Max. - Maximum, $\pm S D$ - standard deviation in the table. 
The mean abdomen length of A. leptodactylus samples from Kilıckaya Reservoir was $57.80 \mathrm{~mm}( \pm \mathrm{SD}$ 5.07 ; min. $53 \mathrm{~mm}$; max. $66 \mathrm{~mm})$. The mean abdomen length of males was $59.33 \mathrm{~mm}( \pm \mathrm{SD} 6.51$; min. $53 \mathrm{~mm}$; max. $66 \mathrm{~mm})$ and mean abdomen length of females was $55.50 \mathrm{~mm}( \pm$ SD $0.71 ; \min .55 \mathrm{~mm}$; $\max .56 \mathrm{~mm}$ ) from Kilçckaya Reservoir. The mean abdomen width of A. leptodactylus samples from Kılıçkaya Reservoir was $20.60 \mathrm{~mm}$ ( \pm SD 2.07; min. $18 \mathrm{~mm}$; max. $23 \mathrm{~mm})$. The mean abdomen width of males was $21.00 \mathrm{~mm}( \pm \mathrm{SD} 2.65$; $\mathrm{min} .18 \mathrm{~mm}$; max. $23 \mathrm{~mm})$ and mean abdomen width of females was $20.00 \mathrm{~mm}$ ( $\pm \mathrm{SD}$ 1.41; min. $19 \mathrm{~mm}$; max. $21 \mathrm{~mm}$ ) from Kulıçkaya Reservoir (Table 1).

The mean cheliped length of $A$. leptodactylus samples from Kilıckaya Reservoir was $46.40 \mathrm{~mm}( \pm \mathrm{SD}$ 15.40; min. $32 \mathrm{~mm}$; max. $66 \mathrm{~mm})$. Mean cheliped length of males was $46.67 \mathrm{~mm}( \pm \mathrm{SD}$ 17.47; min. 32 $\mathrm{mm}$; max. $66 \mathrm{~mm})$ and mean cheliped length of females was $46.00 \mathrm{~mm}( \pm \mathrm{SD} 18.38$; min. $33 \mathrm{~mm}$; max. $59 \mathrm{~mm}$ ) from Kilçkaya Reservoir. The mean cheliped width of A. leptodactylus samples from Kılıçkaya Reservoir was $17.80 \mathrm{~mm}( \pm \mathrm{SD} 4.60$; min. $12 \mathrm{~mm}$; max. $23 \mathrm{~mm})$. Mean cheliped width of males was $18.33 \mathrm{~mm}( \pm \mathrm{SD} 5.69$; $\min .12 \mathrm{~mm}$; $\max .23 \mathrm{~mm})$ and mean cheliped width of females was $17.00 \mathrm{~mm}( \pm \mathrm{SD}$ 4.24; min. $14 \mathrm{~mm}$; max. $20 \mathrm{~mm})$ from Kilıçkaya Reservoir (Table 1).

The value of the total body length for male crayfish varied from to 99 to $131 \mathrm{~mm}(113.33 \mathrm{~mm})$, for female crayfish from 105 to $113 \mathrm{~mm}(109.00 \mathrm{~mm})$, and for the combined sexes crayfish from 99 to $131 \mathrm{~mm}(111.60 \mathrm{~mm})$. The value of the total body weight for male crayfish varied from to 23.27 to

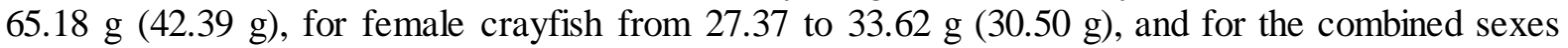
crayfish from 23.27 to $65.18 \mathrm{~mm}(37.63 \mathrm{~mm})$. The condition factor is calculated as 2.40-2.91 for males, and 2.33-2.36 for females. The obtained values for all individuals (Table 1) indicate that the mean condition factor is $2.58 \pm 0.29$ from Kulıçkaya Reservoir.

\section{DIS CUSSION}

Concentrations the preliminary data is first study on some morphometric characters and condition factors of A. leptodactylus from Kılıçkaya Reservoir in Turkey. The morphometric characters would be helpful in comparing the same species in different locations. There are different populations of $A$. leptodactylus in the World and Turkey. It can be concluded that the study of morphometric characters could be used to describe populations [13]. In general, while the body weight of the male individuals of crayfish is greater, and their walking legs and their cheliped wider and longer, the females have a wider and longer abdomen [14]. It has been found in most of the studies done on A. leptodactylus in Turkey that due to the size of their walking legs and their weight, male individuals have a greater average length and weight compared to female individuals [14-16]. Similarly, the mean values that have turned out to be higher for the male population are carapace length, carapace width, abdomen length, abdomen width, cheliped length, cheliped width, total length, total weight and condition factor. All the mean values measured are larger for the male population in comparison to the female population in Kılıçkaya Reservoir. The minimum carapace length is calculated for males (46) as well as maximum (65) from Kilçkaya Reservoir. Similarly, the mean value is greater for males and it is 54.00, while for females is 53.50. The mean carapace length of all A. leptodactylus samples was found to be $53.80 \pm 7.66$ in Kilıçkaya Reservoir (Table 1). The mean carapace length for A. leptodactylus from different habitats in Turkey were reported as $49.94 \mathrm{~mm}$ in Eğirdir Lake, $49.13 \mathrm{~mm}$ in İznik Lake, $50.59 \mathrm{~mm}$ in Hirfanh Dam Lake [17], $48.40 \mathrm{~mm}$ in the Thrace region ponds of Turkey [18], $45.00 \mathrm{~mm}$ in Keban Dam Lake [19], $54.70 \mathrm{~mm}$ in Dikilitaş Pond [20], $49.67 \mathrm{~mm}$ in Mogan Lake [21], $53.74 \mathrm{~mm}$ in Eğirdir Lake [22], $52.46 \mathrm{~mm}$ in Çıldır Lake [23] and $56.18 \mathrm{~mm}$ in Aktaş Lake [24]. The mean carapace length of A. leptodactylus in Kilıckaya Reservoir is greater than those in Eğirdir Lake, in İznik Lake, in Hirfanlı Dam Lake [17], in the Thrace region ponds of Turkey [18], in Keban Dam Lake [19], in Mogan Lake [21] and in Çıldır Lake [23]. The mean carapace width of all $A$.

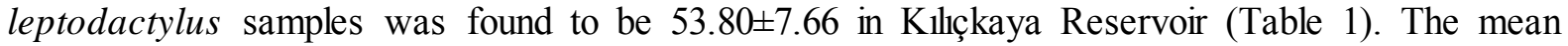
carapace width for A. leptodactylus from different habitats in Turkey were reported as $23.13 \mathrm{~mm}$ in Eğirdir Lake, $21.27 \mathrm{~mm}$ in İznik Lake, $26.06 \mathrm{~mm}$ in Hirfanlı Dam Lake [17], $23.70 \mathrm{~mm}$ in the Thrace region ponds of Turkey [18] and $54.30 \mathrm{~mm}$ in Dikilitaş Pond [20]. The mean carapace width of $A$. leptodactylus in Kıllçkaya Reservoir is smaller than this in Dikilitaş Pond [20].

The mean abdomen length was $59.33 \pm 6.51 \mathrm{~mm}$ for male, $55.50 \pm 0.71 \mathrm{~mm}$ for female and $57.80 \pm 5.07$ $\mathrm{mm}$ for all individuals in Kılıckaya Reservoir (Table 1). The width of male crayfish abdomens was larger than female crayfish abdomens. The mean abdomen length for A. leptodactylus from different 
habitats in Turkey were reported as $31.51 \mathrm{~mm}$ in Terkos Lake [16], $51.88 \mathrm{~mm}$ in Eğirdir Lake, 51.33 $\mathrm{mm}$ in İznik Lake, $54.18 \mathrm{~mm}$ in Hirfanlı Dam Lake [17], $52.60 \mathrm{~mm}$ in the Thrace region ponds of Turkey [18], $56.80 \mathrm{~mm}$ in Dikilitaş Pond [20] and $39.56 \mathrm{~mm}$ in Mogan Lake [21]. The present study was also found that the mean abdomen length was greater than those in Terkos Lake [16], in Eğirdir Lake, in İznik Lake, in Hirfanlı Dam Lake [17], in the Thrace region ponds of Turkey [18], in Dikilitaş Pond [20] and in Mogan Lake [21]. The mean abdomen width of all A. leptodactylus samples was determined as $20.60 \pm 2.07$ in Kılıçkaya Reservoir (Table 1). The mean abdomen width for A. leptodactylus from different habitats in Turkey were reported as $28.70 \mathrm{~mm}$ in Terkos Lake [16], $23.94 \mathrm{~mm}$ in Eğirdir Lake, $20.27 \mathrm{~mm}$ in İznik Lake, $26.00 \mathrm{~mm}$ in Hirfanh Dam Lake [17], $22.2 \mathrm{~mm}$ in the Thrace region ponds of Turkey [18], $19.80 \mathrm{~mm}$ in Dikilitaş Pond [20] and $33.31 \mathrm{~mm}$ in Mogan Lake [21]. The present study was also found that the mean abdomen width was greater than this from Dikilitaş Pond [20].

The minimum cheliped length is calculated for males $(32 \mathrm{~mm})$ as well as maximum $(66 \mathrm{~mm})$ from Kılıçkaya Reservoir. Similarly, the mean value is greater for males and it is $46.67 \mathrm{~mm}$, while for females is $46.00 \mathrm{~mm}$. The mean cheliped length of all A. leptodactylus samples was found to be 46.40 \pm 15.40 in Kilçckaya Reservoir (Table 1). The mean cheliped length for A. leptodactylus from different habitats in Turkey were reported as $52.85 \mathrm{~mm}$ in Terkos Lake [16], $40.44 \mathrm{~mm}$ in Eğirdir Lake, $43.53 \mathrm{~mm}$ in İznik Lake, $32.53 \mathrm{~mm}$ in Hirfanh Dam Lake [17], $37.70 \mathrm{~mm}$ in the Thrace region ponds of Turkey [18], $75.90 \mathrm{~mm}$ in Dikilitaş Pond [20] and $39.33 \mathrm{~mm}$ in Mogan Lake [21]. The present study was also found that the mean abdomen width was smaller than those from Terkos Lake [16] and Dikilitaş Pond [20]. The mean cheliped width of all A. leptodactylus samples was found to be $17.80 \pm 4.60$ in Kilıçkaya Reservoir (Table 1). The mean cheliped width for A. leptodactylus from different habitats in Turkey were reported as $16.53 \mathrm{~mm}$ in Terkos Lake [16], $13.88 \mathrm{~mm}$ in Eğirdir Lake, $15.00 \mathrm{~mm}$ in İznik Lake, $13.36 \mathrm{~mm}$ in Hirfanl Dam Lake [17], $13.10 \mathrm{~mm}$ in the Thrace region ponds of Turkey [18], $14.10 \mathrm{~mm}$ in Dikilitaş Pond [20] and $16.85 \mathrm{~mm}$ in Mogan Lake [21]. Our results were found to be greater than in previous studies.

The total length of A. leptodactylus population in Kulıçkaya Reservoir ranged from 99 to $131 \mathrm{~mm}$. The mean total lengths of female $109.00 \pm 5.66 \mathrm{~g}$ were lower than mean total lengths of male $113.33 \pm 16.26$ in the study area. The mean total length of all A. leptodactylus samples was determined as 111.60 \pm 12.07 in Kilçckaya Reservoir (Table 1). The mean total length for A. leptodactylus from different habitats in Turkey were reported as $102.26 \mathrm{~mm}$ in Dikilitaş Pond [6], $91.06 \mathrm{~mm}$ in Demirköprü Dam Lake [15], $121.33 \mathrm{~mm}$ in Terkos Lake [16], $102.90 \mathrm{~mm}$ in the Thrace region ponds of Turkey [18], $93.0 \mathrm{~mm}$ in Keban Dam Lake [19], $112.30 \mathrm{~mm}$ in Dikilitaş Pond [20], $103.65 \mathrm{~mm}$ in Mogan Lake [21], $106.31 \mathrm{~mm}$ in Eğirdir Lake [22], $154.35 \mathrm{~mm}$ in Keban Dam Lake [25] and $94.75 \mathrm{~mm}$ in Keban Dam Lake [26]. According to these data on A. leptodactylus from the Terkos Lake [16], the Dikilitaş Pond [20] and the Keban Dam Lake [25] show that they are large specimens in terms of total length.

The total weight of A. leptodactylus population in Kilçkaya Reservoir ranged from 23.27 to $65.18 \mathrm{~g}$. The mean total weights of female $30.50 \pm 4.42 \mathrm{~g}$ were lower than mean total weights of male 42.39 \pm 21.19 . The mean total weight of all A. leptodactylus samples was determined as $37.63 \pm 16.49$ in Kilçckaya Reservoir (Table 1). The mean total weight for A. leptodactylus from different habitats in Turkey were reported as $32.66 \mathrm{~g}$ in Dikilitaş Reservoir [6], $25.03 \mathrm{~g}$ in Demirköprü Dam Lake [15], $52.25 \mathrm{~g}$ in Terkos Lake [16], $31.50 \mathrm{~mm}$ in the Thrace region ponds of Turkey [18], $26.6 \mathrm{~g}$ in Keban Dam Lake [19], $46.87 \mathrm{~g}$ in Dikilitaş Pond [20], $32.11 \mathrm{~g}$ in Mogan Lake [21], $40.33 \mathrm{~g}$ in Eğirdir Lake [22], $37.72 \mathrm{~g}$ in Çıldır Lake [23], $41.82 \mathrm{~g}$ in Aktaş Lake [24], $25.44 \mathrm{~g}$ in Keban Dam Lake [25] and $23.61 \mathrm{~g}$ in Keban Dam Lake [26]. According to these data on A. leptodactylus from the Terkos Lake [16], the Dikilitaş Pond [20], Eğirdir Lake [22], Çıldır Lake [23] and Aktaş Lake [24] show that they are large specimens in terms of total weight.

Condition factor values were assessed for male, females and pooled data. The condition factor is the best control of the morphological structure of the A. leptodactylus nutrition and development. The minimum condition factor is calculated for females and it is 2.33 , while the maximum calculated is for males and it is 2.91 (Table 1). The obtained mean value of condition factor for males is $2.74 \pm 0.29$, while for females is slightly lower and it is $2.35 \pm 0.02$ in Kilıçkaya Reservoir. The mean condition factors have slightly greater values in males than in females. The mean value of condition factor for all individuals in the present study was found to be $2.58 \pm 0.29$ which being very close to unity, 
indicates that the A. leptodactylus is in good condition. Similarly, Aydin et al. [14] recorded a mean condition factor value of 2.6 for A. leptodactylus in İznik Lake. Also, Kaya [22] reported the value of the mean condition factor to be 3.31 for A. leptodactylus in Eğirdir Lake for all individuals. The present study was also found that the mean condition factor was smaller than those from Eğirdir Lake [22]. However, the fact that different values have been obtained may be due to differences in the ecological characteristics of the reservoir, different depths of hunting, or that the hunting is carried out at different times.

\section{CONCLUSION}

The present study provide the first data on the some morphometric characters and condition factors of A. leptodactylus population from Kilçkaya Reservoir. First of all, the conservation of the $A$. leptodactylus is of great importance in Kilçkaya Reservoir. According to the morphometric characteristics and condition factors of the A. leptodactylus, it can be concluded that Killçkaya Reservoir has good ecological conditions. Continuous monitoring of A. leptodactylus populations is very important for sustainable ecosystem management. Therefore, it would be advisable to collect more abundant study material and to conduct more detailed studies in the Kılıçkaya Reservoir.

\section{REFERENCES}

[1] Güleç, A.K., Aksu, Ö. (2012). Effects of handling on physiological profiles in Turkish crayfish, Astacus leptodactylus. World Journal of Fish and Marine Sciences, 4(6): 684-688.

[2] Endeizzi, S., Bruno, M.C., Maiolini, B. (2013). Distribution and morphometry of native and alien crayfish in Trentino (Italy). Journal of Limnology, 72(2): 1-12.

[3] Harlığlu, M.M., Güner, U. (2006). Studies on the recently discovered crayfish, Austropotamobius torrentium (Shrank, 1803), in Turkey: morphological analysis and meat yield. Aquaculture Research, 37: $538-542$.

[4] Sağlamtimur, B. (2007). Significance of crayfish in Turkish inland aquatic areas and awaiting threats to crayfish stocks in the future. Turkish Journal of Aquatic Life, 5(8): 57-63.

[5] Kalayc1, G. (2011). Identification of crayfish species in Turkey (Astacus leptodactylus, Austropotamobius torrentium) by PZR-RFLP method. M.Sc. Thesis, Rize University, Graduate School of Appilied and Natural Sciences, Department of Fisheries, Rize, pp 54.

[6] Köksal G., Korkmaz A.S., Kırkağaç M. (2003). Investigation of the crayfish (Astacus leptodactylus Esch. 1823) population in Ankara-Dikilitaş irrigation Reservoir. Ankara University Journal of Agricultural Sciences, 9 (1): 51-58.

[7] Turkstat, 2013. Fishery Statistics, Turkish Statistical Institute, Printing Division, Publication Number: 4349, Ankara, pp 61.

[8] Aydın, H., Harlıoğlu, M.M., Deniz, T. (2012). Harvest, export and economic status of freshwater crayfish (Astacus leptodactylus Eschscholtz, 1823) in Turkey. African Journal of Agricultural Research, 7(16): 2463-2468.

[9] Dirican, S., Musul, H., Çilek, S. (2012). Condition factors of some Cyprinid fishes of Kılıçkaya Reservoir, Sivas, Turkey. Indian Journal of Animal Research, 46(2): 172-175.

[10] Rhodes, C.P., Holdich, D.M. (1984). Length-weight relationship, muscle production and proximate composition of the freshwater crayfish Austropotamobius pallipes (Lereboullet). Aquaculture, 37: 107123.

[11] Harlığlu, M.M. (1999). The relationships between length-weight, and meat yield of freshwater Crayfish, Astacus leptodactylus Eschscholtz, in the Ağın Region of Keban Dam Lake. Turkish Journal of Zoology, 23(3): 949-957.

[12] Pauly, D. (1983). Some simple methods for the assessment of tropical fish stocks. FAO Fisheries Technical Paper No: 234, Rome, Italy, pp 52.

[13] Deniz, T., Aydin, H., Ateş, C. (2013). A study on some morphological characteristics of Astacus leptodactylus (Eschscholtz 1823) in seven different inland waters in Turkey. Journal of Black Sea / Mediterranean Environment, 19: 190-205.

[14] Aydın, H., Harlığlu, M.M., Deniz, T. (2015). An investigation on the population parameters of freshwater crayfish (Astacus leptodactylus Eschscholtz, 1823) in Lake İznik (Bursa). Turkish Journal of Zoology, 39, 660-668.

[15] Balık S., Ustaoğlu M.R., Sarı H.M., Berber S. (2005). Determination of traits some growth and morphometric of crayfish (Astacus leptodactylus Eschscholtz, 1823) at Demirköprü Dam Lake (Manisa). 
Ege Journal of Fisheries and Aquatic Sciences, 22: 83-89.

[16] Güner, U. (2006). Some morphometric characteristics of crayfish (Astacus leptodactylus Eschscholtz, 1823) in Lake Terkos. Ege Journal of Fisheries and Aquatic Sciences, 23(1-2): 163-167.

[17] Harlı̆ğlu, M.M., Harlı̆ğlu, A.G. (2005). The comparison of morphometric analysis and meat yield contents of freshwater crayfish, Astacus leptodactylus (Eschscholtz 1823) caught from İznik, Eğirdir Lakes and Hirfanlı Dam Lake. Science and Engineering Journal of Frrat University, 17(2): 412-423.

[18] Deniz T., Harlığlu, M.M., Deval, M.C. (2010). A study on the morphometric characteristics of Astacus leptodactylus inhabiting the Thrace Region of Turkey. Journal of Knowledge and Management of Aquatic Ecosystems, 397(5): 1-13.

[19] Yüksel, F., Duman, E. (2012). An investigation on some morphological characteristics of crayfish in Keban Dam Lake. Journal of Fisheries Sciences.com, 6(4): 271-281.

[20] Benzer, S., Benzer, R. (2015). Determine some morphological characteristics of crayfish (Astacus leptodactylus Eschscholtz, 1823) with traditional methods and artificial neural networks in Dikilitaş Pond, Ankara, Turkey. Fresenius Environmental Bulletin, 24(11a): 3727-3735.

[21] Benzer, S., Benli, Ç.K., Benzer, R. (2015). The comparison of growth with length-weight relation and artificial neural networks of crayfish, Astacus leptodactylus, in Mogan Lake. Journal Black Sea/Mediterranean Environment, 21(2): 208-223.

[22] Kaya, M.A. (2015). Determination of growth and reproduction properties of freshwater crayfish (Astacus leptodactylus, Eschscholtz, 1823) in Eğirdir Lake-Turkey. M.Sc. Thesis, Süleyman Demirel University, Graduate School of Appilied and Natural Sciences, Department of Fishing and Processing Technology, Is parta, Turkey, pp 72.

[23] Aksu, Ö. Kutluyer, F. (2017). Evaluation of shell pigmentation of freshwater crayfish (Astacus leptodactylus) in Çıldır Lake. I. International Symposium on Limnology and Freshwater Fisheries, LIMNOFISH 2017, 4-6 October 2017, Eğirdir, Isparta, Turkey, Symposium Abstract Book, pp 128.

[24] Aksu, Ö., Kaya, G.K. (2017). The relationships between length-weight, and meat yield of freshwater crayfish (Astacus leptodactylus Eschscholtz, 1823) of Aktaş Lake. Journal of BAUN Institute Science and Technology, 19(2): 283-295.

[25] Demirol, F., Gündüz, F., Yüksel, F., Çoban, M.Z., Beri, A., Kurtoğlu, M., Yıldırım, T., Küçükyılmaz, M. (2015). The investigation of by-catch and discard rates in crayfish (Astacus leptodactylus Eschscholtz, 1823) catching in the Keban Dam Lake. Journal of Limnology and Freshwater Fisheries Research, 1(2): 69-74.

[26] Demirol, F., Gündüz, F., Yüksel, F., Güler, M., Beri, A., Yıldırım, T. (2017). The investigation on reproduction characteristics of crayfish (Astacus leptodactylus Eschscholtz, 1823) in Keban Dam Lake. Yunus Research Bulletin, 2: 125-136.

Citation: S. Dirican, "Predata on Some Morphometric Characters and Condition Factors of Crayfish, Astacus leptodactylus (Eschscholtz, 1823) from Kılıçkaya Reservoir, Sivas, Turkey", International Journal of Innovative Studies in Aquatic Biology and Fisheries, vol. 4, no.1, p. 20-25, 2018. http://dx.doi.org/10.20431/ 2454-7670.0401004

Copyright: (C) 2018 S. Dirican. This is an open-access article distributed under the terms of the Creative Commons Attribution License, which permits unrestricted use, distribution, and reproduction in any medium, provided the original author and source are credited. 